\title{
Fetal Organ Weight
}

National Cancer Institute

\section{Source}

National Cancer Institute. Fetal Organ Weight. NCI Thesaurus. Code C124483.

An estimate or direct measurement of the heaviness of a fetal organ. 